\title{
Vigor Bibit Nangka Tulo setelah Konservasi pada Media Tanam Organik yang Berbeda
}

Tulo Jackfruit Seed Vigority after Conservation Period at Different Organic Growing Media

\author{
Enny Adelina $^{1 *}$, Vanny M.A.Tiwow ${ }^{2}$, dan Adrianton $^{3}$
}

Diterima 13 Mei 2014/Disetujui 30 September 2014

\begin{abstract}
Provision of quality seedling materials by high vigority seedling is one of the important supporting system to the development of commercial-scale jackfruit farms. After passing through a period of jackfruit seed conservation period, the viability of the seed is decreasing, and a proper treatment is needed before planting. Organic growing media for seedling may have beneficial to maintain seedling vigority. The use of waste organic material for improving seed vigority is less researched. The purpose of this experiment was to identify the best growing media for improving Tulo jackfruit seed vigority after a period of conservation. Experiment was conducted using a randomized block design (RBD) factorial design, consisting of a seed source (conservation period) and the type of organic growing media. The experimental results indicated that the source of seedling and growing media affected strongly the leaf area, dry weight and seedling vigor hypothetical index. The interaction between the seedling source and organic growing media showed significant differences in seedling height, stem diameter and leaf numbers.
\end{abstract}

Keywords: seedling vigority, jackfruit, conservation, waste and organic growing media

\begin{abstract}
ABSTRAK
Penyediaan bahan tanam yang bermutu melalui vigor bibit yang tinggi menjadi daya dukung dalam pengembangan tanaman nangka dalam pembuatan kebun-kebun berskala komersial. Setelah melewati periode konservasi benih nangka mengalami penurunan viabilitas sehingga dibutuhkan perlakuan yang tepat ketika penanaman akan dilakukan. Salah satu cara meningkatkan vigor bibit adalah memberikan media tanam organik yang dapat meningkatkan vigor bibit, bahan organik yang berasal dari limbah belum banyak dikaji efektivitasnya dalam meningkatkan vigor bibit. Tujuan percobaan untuk memperoleh media tanam terbaik yang menunjang vigor bibit nangka Tulo setelah periode konservasi. Percobaan dilakukan menggunakan Rancangan Acak Kelompok (RAK) pola faktorial, terdiri dari sumber benih (periode konservasi) dan jenis media tanam organik. Hasil percobaan menunjukkan bahwa sumber benih dan media tanam berpengaruh secara bebas terhadap luas daun, bobot kering bibit dan indeks vigor hipotetik. Interaksi sumber benih dan media tanan organik menunjukkan adanya perbedaan yang nyata terhadap tinggi bibit,diameter batang dan jumlah daun.
\end{abstract}

Kata kunci: vigor bibit, nangka, konservasi, limbah dan media tanam organik

\section{PENDAHULUAN}

Keberhasilan pengusahaan tanaman buah baik kuantitas, kualitas maupun kontinuitasnya terutama yang berskala besar sangat ditentukan oleh ketersediaan bibit bermutu pada waktu yang tepat dalam jumlah besar dan harga terjangkau oleh petani.

Salah satu upaya yang ditempuh adalah melakukan konservasi benih melalui metode penyimpanan yang bertujuan mempertahankan viabilitas benih sepanjang mungkin (Adelina,

\footnotetext{
${ }^{1}$ Program studi Agroteknologi Fakultas Pertanian Universitas Tadulako, ${ }^{2}$ Program studi Kimia PMIPA FKIP Universitas Tadulako, ${ }^{3}$ Program studi Agroteknologi Fakultas Pertanian Universitas Tadulako

Fakultas Pertanian Unversitas Tadulako. Jl. Soekarno-Hatta KM 9 Telp (0451) 429441 Fax (0451)42941-422844

Palu -Sulawesi Tengah 94118. email: ennyadelina@gmail.com (*penulis korespondensi)
} 
Vanny dan Adrianton, 2013) namun penurunan viabilitas pasca konservasi merupakan hal yang tidak mungkin dihindari sehingga upaya pengendalian atau rekayasa lingkungan tumbuh benih dan bibit tetap diperlukan untuk mendapatkan bibit yang berkualitas yang menjamin bibit memiliki vigor bibit yang tinggi ketika akan dipindahkan ke lapangan.

Langkah yang perlu ditempuh untuk meningkatkan vigor bibit pasca benih dikonservasi adalah memberikan media tanam organik yang berpotensi meningkatkan vigor bibit. Media tanam yang dimaksud berupa bahan-bahan organik yang berasal dari limbah atau sampah yang tidak dimanfaatkan lagi namun masih berpotensi dalam meningkatkan kesuburan tanah sebagaimana yang dilaporkan pada penelitian-penelitian sebelumnya.

Rai et al. (2013) menyatakan bahwa komposisi media tanah campuran tanah + pasir + bahan organik dengan perbandingan (v:v:v=3:2:1) menghasilkan pertumbuhan bibit wani tanpa biji terbaik. Sampah kota dan rumput laut merupakan bahan material organik yang baik untuk diolah menjadi bahan organik. Alternatif ini didasari oleh tersedianya sampah kota dan rumput laut dalam jumlah besar di Indonesia khususnya di kota Palu.

Bahan organik yang berasal dari sumber material berbeda tentunya akan memberikan pengaruh yang berbeda pula terhadap pertanaman khususnya pada pertumbuhan bibit yang sumber benihnya berasal dari benihbenih yang mengalami konservasi (stress penyimpanan). Dari penelitian ini diharapkan akan diperoleh teknologi budidaya organik tanaman nangka dalam memenuhi kebutuhan bibit yang bermutu.

\section{BAHAN DAN METODE}

\section{Bahan Penelitian}

Bahan yang digunakan dalam penelitian ini adalah kecambah nangka kultivar Tulo berumur 14 hari yang sebelumnya telah melalui periode konservasi selama 2, 4 dan 6 minggu, topsoil, pasir, pupuk kandang, sampah kota (limbah rumah tangga) hasil fermentasi, rumput laut dan polibag.

\section{Metode Penelitian}

Penelitian dilaksanakan di Laboratorium Ilmu dan Teknologi Benih, Fakultas Pertanian, Universitas Tadulako pada bulan Juli sampai Oktober 2013. Rancangan penelitian yang digunakan Rancangan Acak Kelompok (RAK) dengan perlakuan 2 faktor yaitu faktor pertama periode konservasi benih terdiri dari 3 aras yaitu: 2, 4 dan 6 minggu, faktor kedua media tanam organik terdiri dari 3 aras yaitu: $\mathrm{B} 1=$ tanah + pasir + pupuk kandang, B2 $=$ tanah + pasir + pupuk kandang + sampah kota, B3 = tanah + pasir + pupuk kandang + rumput laut, setiap kombinasi diulang 3 kali. Pengamatan dilakukan selama tiga periode yakni: 3,4 dan 5 minggu setelah tanam. Untuk pengukuran diambil lima sampel acak dari satuan percobaan. Penempatan petak perlakuan dilakukan secara acak sesuai rancangan yang dipergunakan (Gomez dan Gomez, 1995). Peubah amatan yang dilakukan meliputi: tinggi bibit, jumlah daun, bobot kering bibit dan indeks vigor hipotetik.

Semua data yang diperoleh dianalisis secara statistik menggunakan analisis keragaman (ANOVA) dan jika diperoleh pengaruh yang nyata atau sangat nyata dilakukan uji lanjut menggunakan uji DMRT pada taraf $5 \%$.

\section{HASIL DAN PEMBAHASAN}

Hasil penelitian (Gambar 1, 2 dan 3) menunjukkan bahwa benih setelah konservasi 2, 4 dan 6 minggu yang ditanam pada media organik tanah + pasir + pupuk kandang + sampah kota memberikan tinggi bibit, jumlah daun dan diameter batang yang nyata lebih baik pada pengamatan 3,4 dan 5 mst dibandingkan perlakuan lainnya.

Fenomena ini mengindikasikan bahwa konservasi benih selama dua minggu dengan viabilitas benih yang masih tinggi (daya berkecambah 100\%) (Adelina, Vanny dan Adrianton 2014) ketika ditanam pada berbagai media tanam organik dapat menghasilkan bibit yang bervigor tinggi. Vigor bibit tertinggi diperoleh pada media organik tanah + pasir + pupuk kandang + sampah kota diikuti oleh media organik tanah + pasir + pupuk kandang + rumput laut dan paling rendah pada media organik tanah + pasir + pupuk kandang. 
Bertolak dari pengamatan yang dilakukan tampak bahwa benih yang berasal dari hasil konservasi yang lebih lama ternyata menghasilkan vigor bibit yang semakin menurun, hal ini disebabkan benih yang melewati masa konservasi cenderung mengalami kemunduran benih atau mengalami penurunan viabilitas seiring dengan semakin lamanya benih dikonservasi. Penanaman kecambah (benih) yang telah mengalami penurunan viabilitas pada media tanam organik diharapkan dapat meningkatkan vigor bibit.

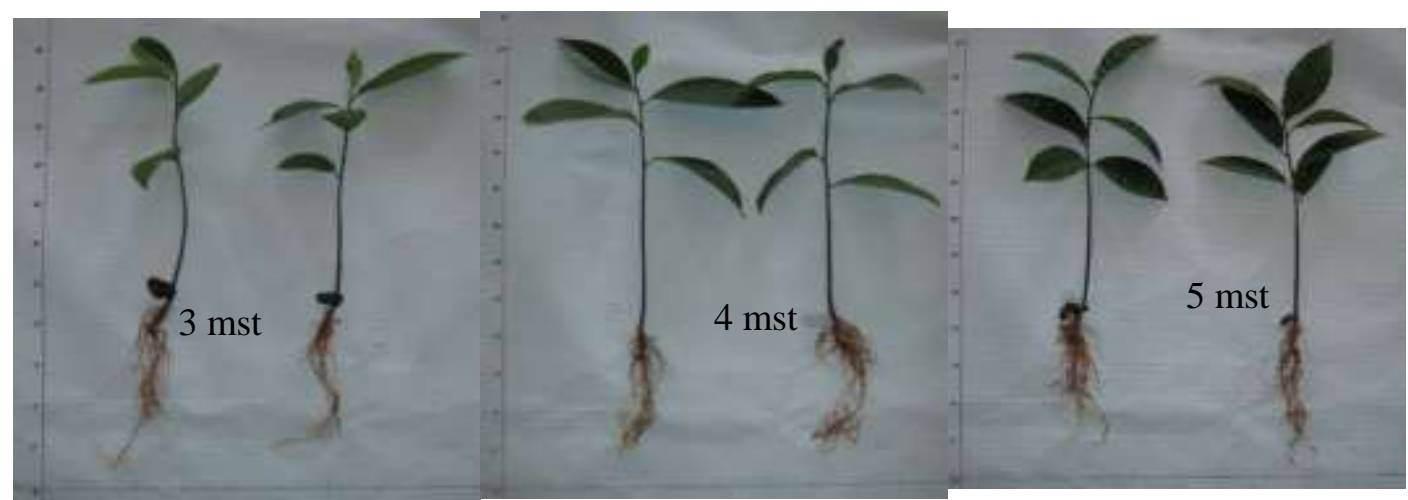

Gambar 1. Vigor bibit nangka setelah konservasi 2 minggu pada media top soil + pupuk kandang + pasir + sampah kota

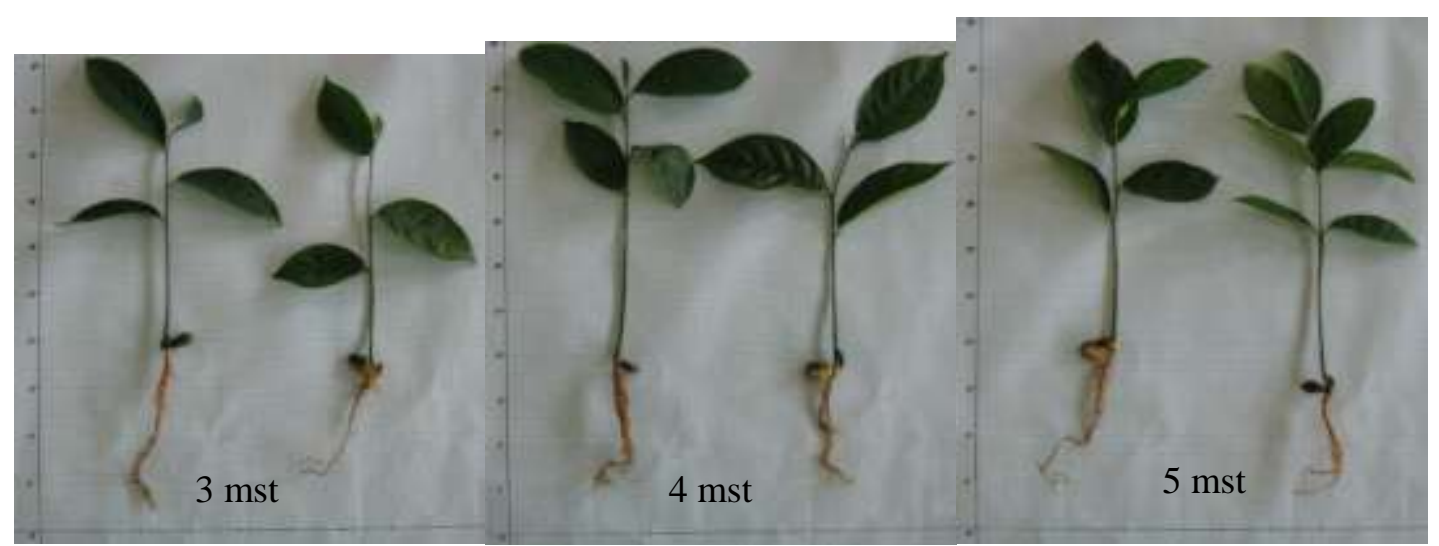

Gambar 2. Vigor bibit nangka setelah konservasi 4 minggu pada media top soil + pupuk kandang + pasir + sampah kota

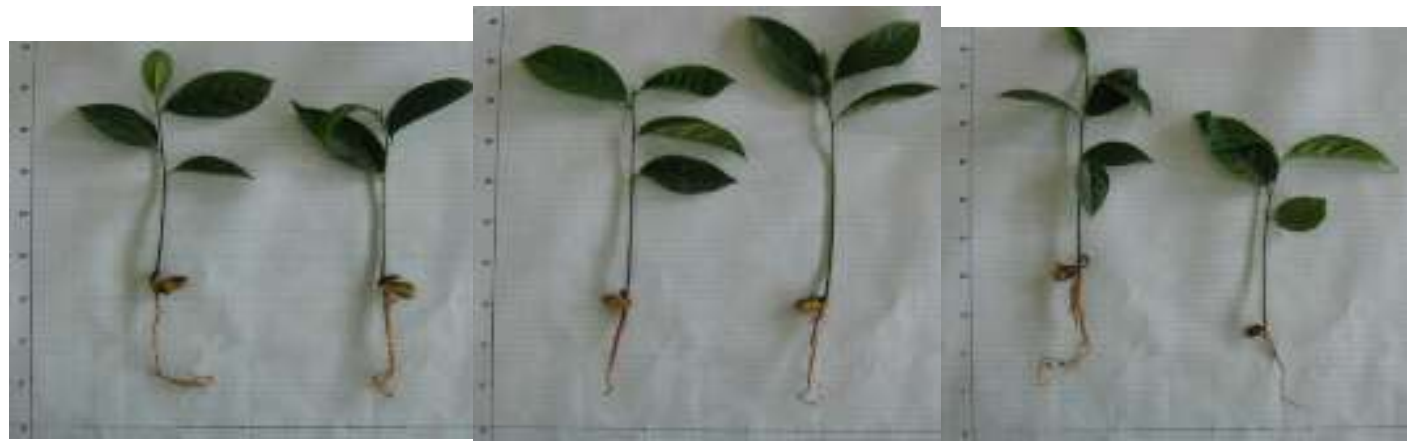

Gambar 3. Vigor bibit nangka setelah konservasi 6 minggu pada media top soil + pupuk kandang + pasir + sampah kota 
Berdasarkan analisis data menunjukkan bahwa Bobot Kering bibit, Luas Daun dan Indeks Vigor Hipotetik tertinggi pada $5 \mathrm{mst}$ diperoleh pada perlakuan benih yang dikonservasi 2 minggu dan ditumbuhkan pada media tanam organik + sampah kota, diikuti oleh perlakuan benih yang di konservasi 4 minggu dan ditumbuhkan pada media tanam organik + sampah kota, diikuti oleh perlakuan benih yang dikonservasi 6 minggu dan ditumbuhkan pada media tanam organik + rumput laut.

Hal ini mengindikasikan bahwa penurunan viabilitas benih akibat konservasi dapat ditingkatkan pertumbuhan bibitnya menggunakan media tanam organik tanah + pasir + pupuk kandang + sampah kota. Upaya mendorong pertumbuhan bibit yang bermutu adalah dengan memperhatikan media pertumbuhan yang digunakan, artinya media tersebut memiliki unsur hara yang cukup untuk diserap tanaman. Kandungan unsur hara pada media tanam dapat ditingkatkan melalui pemupukan baik pupuk organik maupun pupuk anorganik.

Menurut Yuwono (2005) bahan organik merupakan pupuk yang ramah lingkungan dan bersifat sebagai pupuk yang menyediakan unsur hara dalam jangka waktu relatif lebih lama sehingga dapat dimanfaatkan sepanjang masa pertumbuhan tanaman.

Bahan organik dapat mempengaruhi pertumbuhan tanaman secara langsung maupun tidak langsung. Pengaruh langsung adalah melalui peranan komponen organik sederhana seperti vitamin, auksin, asam aromatik dan alifatik terhadap penghambatan dan pemacuan pertumbuhan (Schnitzer, 1991). Pengaruh tidak langsung adalah sebagai sumber hara, mencegah pencucian elemen esensial, meningkatkan kapasitas pertukaran kation, sebagai buffer terhadap perubahan $\mathrm{pH}$ tanah dan salinitas serta meningkatkan daya pegang air tanah (Atmojo, 2003).

Bertolak dari hasil penelitian menunjukkan bahwa perlakuan media tanam memberikan pengaruh sangat nyata dan nyata terhadap seluruh peubah amatan pada 3, 4 dan 5 MST. Perlakuan bahan tanam organik terbukti efektif meningkatkan pertumbuhan bibit yang mencakup tinggi bibit, jumlah daun, diameter batang pada 3, 4, 5 MST dan bobot kering bibit, luas daun dan indeks vigor hipotetik pada 5 MST. (Tabel 1, 2, dan 3)

Tabel 1. Vigor bibit nangka setelah konservasi pada berbagai media tanam organik pada 3 MST

\begin{tabular}{ccccc}
\hline $\begin{array}{c}\text { Kombinasi Lama Konservasi } \\
\text { \& Media Tanam }\end{array}$ & $\begin{array}{c}\text { Tinggi Bibit } \\
(\mathrm{cm})\end{array}$ & $\begin{array}{c}\text { Jumlah Daun } \\
\text { (helai) }\end{array}$ & $\begin{array}{c}\text { Diameter Batang } \\
(\mathrm{cm})\end{array}$ \\
\hline W 1 & B 1 & $35.120 \mathrm{~b}$ & $3.7 \mathrm{a}$ & $0.420 \mathrm{~b}$ \\
W 1 & B 2 & $38.930 \mathrm{c}$ & $3.8 \mathrm{~b}$ & $0.477 \mathrm{c}$ \\
W 1 & B 3 & $37.900 \mathrm{c}$ & $2.9 \mathrm{a}$ & $0.390 \mathrm{a}$ \\
W 2 & B 1 & $32.913 \mathrm{~b}$ & $2.8 \mathrm{a}$ & $0.373 \mathrm{a}$ \\
W 2 & B 2 & $33.880 \mathrm{~b}$ & $2.8 \mathrm{a}$ & $0.360 \mathrm{a}$ \\
W 2 & B 3 & $31.907 \mathrm{~b}$ & $2.8 \mathrm{a}$ & $0.380 \mathrm{a}$ \\
W 3 & B 1 & $30.850 \mathrm{~b}$ & $2.4 \mathrm{a}$ & $0.357 \mathrm{a}$ \\
W 3 & B 2 & $31.780 \mathrm{~b}$ & $2.2 \mathrm{a}$ & $0.370 \mathrm{a}$ \\
W 3 & B 3 & $25.867 \mathrm{a}$ & $2.4 \mathrm{a}$ & $0.350 \mathrm{a}$ \\
\hline
\end{tabular}

Keterangan:

$\mathrm{W} 1$ = periode konservasi 2 (dua) minggu $\mathrm{B} 1=$ media tanam tanah+pasir + pupuk kandang

$\mathrm{W} 2$ = periode konservasi 4 (empat) minggu B2 = media tanam tanah+pasir+pupuk kandang+sampah kota

$\mathrm{W} 3=$ periode konservasi 6 (enam) minggu B3 = media tanam tanah+pasir+pupuk kandang+rumput laut 
Tabel 2. Vigor bibit nangka setelah konservasi pada berbagai media tanam organik pada 4 MST

\begin{tabular}{ccccc}
\hline \multicolumn{2}{c}{$\begin{array}{c}\text { Kombinasi Lama } \\
\text { Konservasi \& Media } \\
\text { Tanam }\end{array}$} & $\begin{array}{c}\text { Tinggi Bibit } \\
(\mathrm{cm})\end{array}$ & $\begin{array}{c}\text { Jumlah Daun } \\
\text { (helai) }\end{array}$ & Diameter Batang \\
W 1 & B 1 & $39.733 \mathrm{~b}$ & $3.7 \mathrm{a}$ & $0.430 \mathrm{~b}$ \\
W 1 & B 2 & $46.843 \mathrm{c}$ & $4.5 \mathrm{~b}$ & $0.493 \mathrm{c}$ \\
W 1 & B 3 & $44.133 \mathrm{c}$ & $3.4 \mathrm{a}$ & $0.400 \mathrm{a}$ \\
W 2 & B 1 & $37.847 \mathrm{~b}$ & $3.3 \mathrm{a}$ & $0.387 \mathrm{a}$ \\
W 2 & B 2 & $39.140 \mathrm{~b}$ & $3.3 \mathrm{a}$ & $0.393 \mathrm{a}$ \\
W 2 & B 3 & $36.953 \mathrm{~b}$ & $3.3 \mathrm{a}$ & $0.387 \mathrm{a}$ \\
W 3 & B 1 & $35.973 \mathrm{~b}$ & $2.7 \mathrm{a}$ & $0.381 \mathrm{a}$ \\
W 3 & B 2 & $32.133 \mathrm{a}$ & $2.8 \mathrm{a}$ & $0.387 \mathrm{a}$ \\
W 3 & B 3 & $29.820 \mathrm{a}$ & $3.1 \mathrm{a}$ & $0.375 \mathrm{a}$ \\
\hline
\end{tabular}

Keterangan:

$\mathrm{W} 1$ = periode konservasi 2 (dua) minggu $\mathrm{B} 1=$ media tanam tanah+pasir+pupuk kandang

$\mathrm{W} 2$ = periode konservasi 4 (empat) minggu B2 = media tanam tanah+pasir+pupuk kandang+sampah kota

$\mathrm{W} 3=$ periode konservasi $6(\mathrm{enam})$ minggu B3 = media tanam tanah+pasir+pupuk kandang+rumput laut

Tabel 3. Vigor bibit nangka setelah konservasi pada berbagai media tanam organik pada 5 MST

\begin{tabular}{|c|c|c|c|c|c|c|c|}
\hline \multicolumn{2}{|c|}{$\begin{array}{c}\text { Kombinasi Lama } \\
\text { Konservasi \& } \\
\text { Media Tanam }\end{array}$} & $\begin{array}{l}\text { Tinggi } \\
\text { Bibit } \\
(\mathrm{cm})\end{array}$ & $\begin{array}{c}\text { Jumlah } \\
\text { Daun } \\
\text { (helai) }\end{array}$ & $\begin{array}{c}\text { Diameter } \\
\text { Batang } \\
(\mathrm{cm})\end{array}$ & $\begin{array}{c}\text { Bobot } \\
\text { Kering } \\
(\mathrm{g})\end{array}$ & $\begin{array}{l}\text { Luas } \\
\text { Daun } \\
\left(\mathrm{cm}^{2}\right)\end{array}$ & IVH \\
\hline W 1 & B 1 & $44.360 \mathrm{~b}$ & $4.0 \mathrm{~b}$ & $0.460 \mathrm{~b}$ & $1.780 \mathrm{c}$ & $40.300 \mathrm{a}$ & $5.384 \mathrm{e}$ \\
\hline W 1 & B 2 & $51.300 \mathrm{c}$ & $5.2 \mathrm{c}$ & $0.530 \mathrm{c}$ & $1.850 \mathrm{c}$ & $58.300 \mathrm{~b}$ & $5.988 \mathrm{f}$ \\
\hline W 1 & B 3 & $49.167 \mathrm{c}$ & $3.5 \mathrm{~b}$ & $0.420 \mathrm{a}$ & $1.737 \mathrm{c}$ & $50.933 \mathrm{~b}$ & $5.449 \mathrm{e}$ \\
\hline W 2 & B 1 & $41.760 \mathrm{~b}$ & $3.5 \mathrm{~b}$ & $0.400 \mathrm{a}$ & $1.620 \mathrm{~b}$ & $36.767 \mathrm{a}$ & $5.059 \mathrm{c}$ \\
\hline W 2 & B 2 & $43.567 \mathrm{~b}$ & $3.8 \mathrm{~b}$ & $0.413 \mathrm{a}$ & $1.633 \mathrm{~b}$ & $55.700 \mathrm{~b}$ & $5.438 \mathrm{e}$ \\
\hline W 2 & B 3 & $41.193 \mathrm{~b}$ & $3.4 \mathrm{~b}$ & $0.393 \mathrm{a}$ & $1.597 \mathrm{~b}$ & $47.633 \mathrm{a}$ & $5.181 \mathrm{~d}$ \\
\hline W 3 & B 1 & $37.970 \mathrm{~b}$ & $2.9 \mathrm{a}$ & $0.383 \mathrm{a}$ & $1.443 \mathrm{a}$ & $34.000 \mathrm{~b}$ & $4.750 \mathrm{a}$ \\
\hline W 3 & B 2 & $39.273 \mathrm{~b}$ & $3.6 \mathrm{~b}$ & $0.393 \mathrm{a}$ & $1.577 \mathrm{~b}$ & $51.333 \mathrm{~b}$ & $5.227 \mathrm{~d}$ \\
\hline W 3 & B 3 & $35.220 \mathrm{a}$ & $3.3 \mathrm{~b}$ & $0.370 \mathrm{a}$ & $1.433 \mathrm{a}$ & $44.533 \mathrm{~b}$ & $4.912 \mathrm{~b}$ \\
\hline
\end{tabular}

Keterangan:

$\mathrm{W} 1$ = periode konservasi 2 (dua) minggu B1 = media tanam tanah+pasir+pupuk kandang

$\mathrm{W} 2$ = periode konservasi 4 (empat) minggu B2 = media tanam tanah+pasir+pupuk kandang+sampah kota

$\mathrm{W} 3$ = periode konservasi 6 (enam) minggu B3 = media tanam tanah+pasir+pupuk kandang+rumput laut

$\mathrm{IVH}=$ indeks vigor hipotetik

Berdasarkan hasil analisis data menunjukkan media tanam organik sampah kota memberikan hasil lebih tinggi dibandingkan media tanam organik lainnya khususnya pada benih yang berasal dari konservasi 2 minggu hal ini disebabkan media tanam organik sampah kota merupakan hasil fermentasi sampah organik dengan menggunakan aktivator mikro organisme alami atau bioaktivator yang memperbaiki sifat fisik, kimia dan biologi tanah sehingga kesuburan tanah menjadi lebih baik. Menurut Khakim (2011) dalam setiap 100 gram pupuk organik sampah kota mengandung nitrogen $0.19-1.5 \%$, fosfor $0.08-0.27$ dan kalium $0.45-1.2$.
Media tanam organik rumput laut memberikan pengaruh yang cukup baik terhadap pertumbuhan bibit sebab menurut Montano dan Tupas (1990) rumput laut mengandung zat pengatur tumbuh tanaman sehingga efektif dalam meningkatkan metabolisme dalam proses pertumbuhan bibit, disamping itu rumput laut juga mengandung gel yang mempunyai kemampuan menyerap air sehingga menambah kelembaban media tanam. 


\section{KESIMPULAN}

Media tanam organik sampah kota dan rumput laut terbukti efektif dalam menghasilkan vigor bibit nangka yang tinggi, namun efektifitas media tanam juga ditentukan oleh viabilitas awal benih yang digunakan. Semakin tinggi viabilitas awal benih akan semakin tinggi pula vigor bibit yang dihasilkan.

\section{SARAN}

Pemakaian media tanam organik terbukti nyata memberikan respon positip bagi pertumbuhan bibit namun perlu dipertimbangkan bahan organik sampah kota tidak homogen sehingga komposisi kimianya akan berubah-ubah setiap waktu sehingga tidak dapat dipertahankan kajian ilmiahnya, sedangkan media tanam organik rumput laut komposisi kimianya stabil sehingga kajian ilmiahnya dapat dipertahankan.

\section{DAFTAR PUSTAKA}

Adelina, E, Vanny Tiwow, Adrianton, 2013. Metode Konservasi Benih Nangka Unggulan Palu Tahan Kekeringan Guna Pengadaan Benih Bermutu. Universitas Tadulako, Laporan Akhir PUPT I. Desember 2013

Adelina, E, Vanny Tiwow, Adrianton, 2014. Metode Konservasi Benih Nangka Unggulan Palu Tahan Kekeringan Guna Pengadaan Benih Bermutu. Universitas
Tadulako, Laporan Akhir PUPT II. November 2014

Atmojo, W.S. 2013. Peranan Bahan Organik terhadap Kesuburan Tanah.

Gomez, K.A., A.A. Gomez. 1995. Statistical Procedures for Agricultural Research. JohnWilley and Sons.

Khakim, N.R. 2001. Pengaruh Bokasi sampah kota dan Saferto-5 terhadap pertumbuhan dan produksi tanaman mentimun (Cucumis sativus.L) Skripsi. Universitas Widyagama Malang.

Montano, N.E., L.M. Tupas, 1990. Plant Growth Hormonal Activities of Aqueous Extractes from Phillippines Seaweeds. Marine Science Institute. University of Philipines

Rai, I.N., C.G.A. Semarajaya, I.W Wiraatmaja, N.K.A. Astari. 2013. Respon pertumbuhan bibit Wani tanpa biji (Mangifera caesia Jack var. Ngumpen Bali) pada berbagai komposisi media tumbuh. J. Hort. Indonesia. 4(2): 77-82.

Sadjad, S., 1993. Dari Benih kepada Benih. Grasindo. Jakarta. p. 144.

Schinetzer. M, 1991. Soil organic matter- the next 75 years. Soil Sci. 151:41-58.

Yuwono, D. 2005. Kompos Penebar Swadaya. Jakarta. 